\title{
Management of Wilt and Root Rot of Chickpea caused by Fusarium oxysporum f. sp. ciceri and Macrophomina phaseolina through Seed Biopriming and Soil Application of Bio-Agents
}

\author{
R.N. Pandey, N.M. Gohel* and Pratik Jaisani \\ Department of Plant Pathology, B. A. College of Agriculture, Anand Agricultural University, \\ Anand - 388 110, Gujarat, India \\ *Corresponding author
}

\author{
A B S T R A C T
}

\begin{tabular}{|l|}
\hline Ke y w o r d s \\
$\begin{array}{l}\text { Trichoderma spp., } \\
\text { Pseudomonas } \\
\text { fluorescens, Seed } \\
\text { biopriming, wilt, } \\
\text { root rot, Fusarium } \\
\text { oxysporum f.sp. } \\
\text { ciceri, } \\
\text { Macrophomina } \\
\text { phaseolina. }\end{array}$ \\
\hline Article Info \\
\hline $\begin{array}{l}\text { Accepted: } \\
\text { 25 April } 2017 \\
\text { Available Online: } \\
\text { 10 May } 2017\end{array}$ \\
\hline
\end{tabular}

Wilt and root rot diseases of chickpea caused by Fusarium oxysporum f. sp. ciceri and Macrophomina phaseolina are serious biotic constraints for chickpea (Cicer arietinum L.) production. These are most important and widespread soil- and seed-borne diseases of chickpea grown where the climate is relatively dry and warm. To find out the effective management of the diseases through seed biopriming and soil application of biocontrol agents, the field studies were conducted during Rabi season of 2013-14 and 2014-15. Seed biopriming checked the incidence of wilt and root rot in the range of $45 \%-60 \%$ and increased the yield of chickpea by $10 \%-20 \%$. However, combined applications of seed biopriming as well as soil application significantly checked the disease incidence in the range of $46 \%-78 \%$ and increased the grain yield by $13 \%-27 \%$. The disease control and yield enhancement were highest with $T$. viride followed by $T$. harzianum. The pooled result of two years revealed that soil application of Trichoderma viride or T. harzianum $\left(2 \times 10^{8} \mathrm{cfu} / \mathrm{g}\right)$ enriched FYM (10 kg bioagent/ ton FYM) in furrow @ 1 ton/ ha, followed by seed biopriming at the time of sowing i.e. soaking of chickpea seeds for $10 \mathrm{hrs}$ in suspension of talc based formulation $1 \% \mathrm{WP}\left(2 \times 10^{8} \mathrm{cfu} / \mathrm{g}\right)$ of $T$. viride or T. harzianum, respectively @ $50 \mathrm{~g}$ product/ $250 \mathrm{ml}$ of water/ $\mathrm{kg}$ seed and shade dried for the effective management of wilt and root rot complex.

\section{Introduction}

Wilt and root rot are the common and frequently occurring diseases of chickpea and causes considerable yield loss (Haware et al., 1996; Kaur and Mukhopadhyay, 1992). Fusarium oxysporum f. sp. ciceri (Padwick) Synd. and Hans. is considered to be the primary cause of wilt disease in chickpea (Chattopadhyay and Sen Gupta, 1967), whereas, Rhizoctonia solani Kuhn is concomitantly associated with the disease (Bhatti et al., 1987; Jalali and Chand, 1992).
$R$. solani alone is capable of causing wet root rot (Singh, 2005), but its occurrence with $F$. oxysporum f. sp. ciceri has been observed quite frequently (Andrabi et al., 2011). India is a major chickpea growing country producing around $75 \%$ of the world's supply (Tomar et al., 2010). Chickpea wilt and root rot are soil- and seed-borne; facultative saprophyte and survive in soil for two to three years (Haware et al., 1978). These cause complete losses in grain yield, if the diseases 
occur in the vegetative and reproductive stages of the crop (Haware and Nene, 1980). Researches have shown that commonly grown cultivars of chickpea in India may suffer from 9-41\% seed yield loss due to wilt, depending on the cultivar and disease severity (Khan et al., 2004).

Biological control is one of the best low-cost and ecologically sustainable methods for managing plant diseases caused by soil-borne pathogens like Fusarium, Macrophomina, Rhizoctonia, etc. Among various biocontrol agents (BCAs) evaluated against the plant pathogenic fungi, Trichoderma spp. have been found to possess biocontrol ability (Abd El-Khair et al., 2010; Mohiddin et al., 2010), these fungi mycoparasitize the pathogenic fungi via hyphal coiling and enabling enzymatic lysis through 1, 3-glucanase, cellulase, chitinase, and proteinase (Jefries and Young, 1994). Trichoderma species can also combat plant pathogens by exerting antagonism in the form of antibiosis; the production of antifungal metabolites such as trichodermin, gliotoxin, or viridin (Bruckner and Przybylski, 1984; Lorito et al., 1993). Research shows that seed and soil applications of different strains of $T$. harzianum and $T$. viride successfully control root rot and wilt disease caused by $R$. solani and $F$. oxysporum f. sp. ciceri under pot conditions (Rudresh et al., 2005; Kumar et $a l ., 2008$ ) and field conditions (Prasad et al., 2002; Dubey et al., 2012). However, these studies have tested two or three strains of Trichoderma spp. against monopathogenic diseases caused by Fusarium or Macrophomina or Rhizoctonia spp. Information on the relative effectiveness of important species of Trichoderma under multipathogenic conditions is largely lacking. The present study was undertaken to examine the performance of three important species of Trichoderma (T. viride, T. harzianum and $T$. virens), as well as Pseudomonas fluorescens through seed biopriming and soil application with the objective to evaluate the bioefficacy of bioagents as well as to assess the effect of the bioagents in growth and yield parameters of the chickpea.

\section{Materials and Methods}

The study was conducted at College Agronomy Farm, B. A. College of Agriculture, Anand Agricultural University, Anand during two consecutive years in the Rabi: 2013-14 and 2014-15 in Randomized Block Design with ten treatments along with three replications using cultivar Gujarat Gram 2 . The crop was sown with $30 \times 10 \mathrm{~cm}$ spacing having a gross plot size of $5.0 \times 3.0 \mathrm{~m}$ and net plot size of $4.8 \times 2.4 \mathrm{~m}$. The seed rate was used at $50 \mathrm{~kg} / \mathrm{ha}$. The bioagents were used in the present investigations were $T$. viride, $T$. harzianum, $T$. virens and $P$. fluorescens.

The seeds of chickpea were treated with suspension of talc-based formulation of Trichoderma spp. and $P$. fluorescens multiplied by liquid fermentation individually (2x108 cfu/g) @ $50 \mathrm{~g}$ product/ $250 \mathrm{ml}$ of water $/ \mathrm{kg}$ of seed for $10 \mathrm{hrs}$. The bioprimed seeds were shade dried. An untreated control was also maintained. Similarly, the soil application of bioagents $\left(2 \times 10^{8} \mathrm{cfu} / \mathrm{g}\right)$ enriched FYM (10 kg bioagent/ ton FYM) in furrow @ 1 ton/ ha was done as per treatments. The observations were recorded on seed germination (\%), growth parameters i.e. root and shoot length $(\mathrm{cm})$, vigour index, wilt and root rot (complex) incidence (\%) and grain yield ( $\mathrm{kg} / \mathrm{ha})$.

The percent disease incidence (PDI) was calculated by using the following formula:

Disease incidence $(\%)=$ Total No. of diseased plants/ Total No. of Plants x 100

The seedling vigour index was calculated using the formula as given by Abdul Baki and Anderson (1973). 
Vigour index $=($ Mean root length + Mean shoot length) $x$ Per cent germination

\section{Results and Discussion}

The pooled data of the year: 2013-14 and 2014-15 for the management of wilt - root rot complex of chickpea through seed biopriming and soil application of bioagents (Table 1) revealed significantly lowest incidence of wilt and root rot $(8.59 \%)$ and highest seed germination (96.69\%), vigour index (2734) and grain yield $(1535 \mathrm{~kg} / \mathrm{ha})$ in the treatment $\mathrm{T}_{5}$ i.e. seed biopriming for $10 \mathrm{hrs}$ with suspension of talc based formulation (2x108 cfu/g) of T.viride @ $50 \mathrm{~g}$ in $250 \mathrm{ml}$ of water/ $\mathrm{kg}$ of seed + soil application of $T$. viride enriched FYM (10 kg bioagent/ ton FYM) in furrow@1 ton/ ha, which was on par with the treatment T6 i.e. seed biopriming for 10 hrs with suspension of talc based formulation (2x108 cfu/g) of T. harzianum @ $50 \mathrm{~g}$ in 250 $\mathrm{ml}$ of water/ $\mathrm{kg}$ of seed + soil application of $T$. harzianum enriched FYM (10 kg bioagent/ ton FYM) in furrow @ 1 ton/ ha having low incidence of wilt and root rot $(9.78 \%)$ and higher seed germination $(94.34 \%)$, vigour index (2552) and grain yield (1466 kg/ha) as compared to untreated check, which recorded highest incidence of wilt - root rot complex $(38.53 \%)$ and lowest grain yield of 1117 $\mathrm{kg} / \mathrm{ha}$.

Considering the efficacy, additional income and ICBR of the treatments (Table 2), treatment $T_{5}$ and $T_{6}$ i.e. seed biopriming for $10 \mathrm{hrs}$ with suspension of talc based formulation $\left(2 \times 10^{8} \mathrm{cfu} / \mathrm{g}\right)$ of $T$. viride $\left(\mathrm{T}_{5}\right)$ or T. harzianum $\left(\mathrm{T}_{6}\right) @ 50 \mathrm{~g}$ in $250 \mathrm{ml}$ of water/ $\mathrm{kg}$ of seed + soil application of $T$. viride $\left(\mathrm{T}_{5}\right)$ or $T$. harzianum $\left(\mathrm{T}_{6}\right)$ enriched FYM $(10 \mathrm{~kg}$ bioagent/ ton FYM) in furrow @ 1 ton/ ha was found significantly effective for disease management $(8.59 \%$ and $9.78 \%$ disease incidence, respectively) and economical
(ICBR 1: 10.09 and ICBR 1: 8.42, respectively) in reducing the wilt and root rot incidence of chickpea.

Khan et al., (2014) studied the effects of $T$. harzianum, $T$. hamatum, $T$. viride, $T$. polysporum, and $T$. koningii on the wilt disease complex of chickpea caused by Fusarium oxysporum f. sp. ciceri and $R$. solani. Soil application of biocontrol agents checked the severity of wilt by $25 \%-56 \%$ and $39 \%-67 \%$ and increased the yield of chickpea by $12 \%-28 \%$ and $8 \%-24 \%$ in the two years i.e. 2004-2006, respectively. The disease control and yield enhancement were highest with $T$. harzianum, followed by $\mathrm{T}$. hamatum and $T$. viride.

Manjunatha et al., (2013) reported minimum root rot incidence of chickpea $(2.67 \%)$ with higher seed germination $(97.60 \%)$ and seed yield (1274 kg/ha) achieved through seed treatment of $T$. viride + soil application of FYM at $4 \mathrm{~kg} /$ plot.

Rudresh et al., (2005) reported significant control of wet root rot and Fusarium wilt of chickpea by soil application of $T$. harzianum (PDBCTH) and $T$. virens (PDBCTV12), respectively. However, in another study, Kumar et al., (2008) found T. virens was more effective than $T$. harzianum against $R$. solani. Malathi and Sabitha (2004) studied the effect of seed priming with Trichoderma spp. i.e. $T$. viride, $T$. harzianum, $T$. hamatum, $T$. longibrachiatum, $T$. koningii and $T$. pseudokoningii on seed-borne infection of $M$. phaseolina in groundnut and found that seed pelleting with Trichoderma spp. protected seeds from $M$. phaseolina infection and maximum reduction of infection $(79.6 \%)$ was shown by $T$. harzianum and also it improved seedling vigour, dry matter production and prevented loss of oil content up to six months of storage. 
Table.1 Effect of seed biopriming and soil application of bioagents on growth parameters, wilt-root rot incidence and yield of chickpea

\begin{tabular}{|c|c|c|c|c|c|c|c|c|c|}
\hline $\begin{array}{l}\text { Tr } \\
\text { No }\end{array}$ & Treatment & $\begin{array}{c}\text { Germi- } \\
\text { nation }(\%)\end{array}$ & $\begin{array}{l}\text { Shoot } \\
\text { Length } \\
\text { (cm) }\end{array}$ & $\begin{array}{l}\text { Root } \\
\text { Length } \\
(\mathbf{c m})\end{array}$ & $\begin{array}{l}\text { Vigour } \\
\text { Index } \\
\text { (VI) }\end{array}$ & $\begin{array}{l}\text { Wilt and } \\
\text { root rot } \\
\text { incidence } \\
\quad(\%)\end{array}$ & $\begin{array}{l}\text { \% disease } \\
\text { control } \\
\text { over } \\
\text { check }\end{array}$ & $\begin{array}{l}\text { Grain } \\
\text { yield } \\
\text { (kg/ha) }\end{array}$ & $\begin{array}{c}\% \\
\text { Increase } \\
\text { of yield } \\
\text { over } \\
\text { check }\end{array}$ \\
\hline $\mathbf{T}_{1}$ & $\begin{array}{l}\text { Seed biopriming for } 10 \mathrm{hrs} \text { with suspension of talc based formulation } \\
\left(2 \times 10^{8} \mathrm{cfu} / \mathrm{g}\right) \text { of Trichoderma viride @ } 50 \mathrm{~g} \text { in } 250 \mathrm{ml} \text { of water } / \mathrm{kg} \text { of } \\
\text { seed }\end{array}$ & $\begin{array}{l}74.19 \mathrm{abc} \\
(92.58)\end{array}$ & 23.84 abc & $8.21 \mathrm{bc}$ & $2379 \mathrm{bc}$ & $\begin{array}{l}23.36 \mathrm{c} \\
(15.72)\end{array}$ & 59.20 & $1392 \mathrm{abc}$ & 19.76 \\
\hline $\mathbf{T}_{2}$ & $\begin{array}{l}\text { Seed biopriming for } 10 \mathrm{hrs} \text { with suspension of talc based formulation } \\
\left(2 \times 10^{8} \mathrm{cfu} / \mathrm{g}\right) \text { of Trichoderma harzianum @ } 50 \mathrm{~g} \text { in } 250 \mathrm{ml} \text { of } \\
\text { water } / \mathrm{kg} \text { of seed }\end{array}$ & $\begin{array}{l}73.05 \mathrm{bcd} \\
(91.50)\end{array}$ & $23.15 b c$ & $8.10 \mathrm{bcd}$ & $2279 \mathrm{~cd}$ & $\begin{array}{l}24.41 \mathrm{bc} \\
(17.08)\end{array}$ & 55.67 & $1330 \mathrm{bcd}$ & 16.02 \\
\hline $\mathbf{T}_{3}$ & $\begin{array}{l}\text { Seed biopriming for } 10 \mathrm{hrs} \text { with suspension of talc based formulation } \\
\left(2 \times 10^{8} \mathrm{cfu} / \mathrm{g}\right) \text { of Trichoderma virens @ } 50 \mathrm{~g} \text { in } 250 \mathrm{ml} \text { of water } / \mathrm{kg} \text { of } \\
\text { seed }\end{array}$ & $\begin{array}{l}69.44 \text { cde } \\
(87.67)\end{array}$ & $22.48 \mathrm{~cd}$ & 7.93 bcde & $2114 \mathrm{de}$ & $\begin{array}{l}25.70 \mathrm{bc} \\
(18.81)\end{array}$ & 51.18 & $1313 \mathrm{~cd}$ & 14.93 \\
\hline $\mathbf{T}_{4}$ & $\begin{array}{l}\text { Seed biopriming for } 10 \mathrm{hrs} \text { with suspension of talc based formulation } \\
\left(2 \times 10^{8} \mathrm{cfu} / \mathrm{g}\right) \text { of Pseudomonas fluorescens @ } 50 \mathrm{~g} \text { in } 250 \mathrm{ml} \text { of } \\
\text { water } / \mathrm{kg} \text { of seed }\end{array}$ & $\begin{array}{l}67.58 \mathrm{de} \\
(85.45)\end{array}$ & $21.03 \mathrm{~d}$ & $7.31 \mathrm{de}$ & $1914 \mathrm{e}$ & $\begin{array}{l}27.54 \mathrm{~b} \\
(21.38)\end{array}$ & 44.51 & $1230 \mathrm{de}$ & 9.19 \\
\hline $\mathbf{T}_{5}$ & $\begin{array}{l}\mathrm{T}_{1}+\text { Soil application of } T \text {. viride enriched FYM (10g/ kg FYM) @ } 100 \\
\mathrm{~g} / \mathrm{m}^{2} \text { of soil }\end{array}$ & $\begin{array}{l}79.51 \mathrm{a} \\
(96.69)\end{array}$ & $25.22 \mathrm{a}$ & $9.12 \mathrm{a}$ & $2734 \mathrm{a}$ & $\begin{array}{l}17.04 \mathrm{e} \\
(8.59)\end{array}$ & 77.72 & $1535 \mathrm{a}$ & 27.23 \\
\hline$T_{6}$ & $\begin{array}{l}\mathrm{T}_{2}+\text { soil application of } T \text {. harzianum enriched FYM (10g/ kg FYM) @ } \\
100 \mathrm{~g} / \mathrm{m}^{2} \text { soil }\end{array}$ & $\begin{array}{l}76.24 \mathrm{ab} \\
(94.34)\end{array}$ & $24.79 \mathrm{ab}$ & $8.71 \mathrm{ab}$ & $2552 a b$ & $\begin{array}{l}18.22 \mathrm{de} \\
(9.78)\end{array}$ & 74.62 & $1466 a b$ & 23.81 \\
\hline $\mathbf{T}_{7}$ & $\begin{array}{l}\mathrm{T}_{3}+\text { soil application of } T . \text { virens enriched FYM (10g/ kg FYM) @ } 100 \\
\mathrm{~g} / \mathrm{m}^{2} \text { soil }\end{array}$ & $\begin{array}{l}74.29 \mathrm{abc} \\
(92.67)\end{array}$ & $24.43 a b c$ & $8.28 \mathrm{abc}$ & $2426 \mathrm{bc}$ & $\begin{array}{l}20.14 \mathrm{~d} \\
(11.86)\end{array}$ & 69.22 & $1457 \mathrm{ab}$ & 23.33 \\
\hline $\mathbf{T}_{8}$ & $\begin{array}{l}\mathrm{T}_{4}+\text { soil application of } P . \text { fluorescens } \text { enriched FYM (10g/ kg FYM) } \\
\text { @ } 100 \mathrm{~g} / \mathrm{m}^{2} \text { soil }\end{array}$ & $\begin{array}{l}68.29 \mathrm{de} \\
(86.32)\end{array}$ & $20.65 \mathrm{~d}$ & 7.57 cde & 1929 e & $\begin{array}{l}27.14 \mathrm{~b} \\
(20.81)\end{array}$ & 45.99 & $1285 \mathrm{~cd}$ & 13.07 \\
\hline $\mathbf{T}_{9}$ & $\begin{array}{l}\text { Hydropriming of seed i.e. soaking of chickpea seed @ } 250 \mathrm{ml} \text { of } \\
\text { water/kg seed for } 10 \mathrm{hrs} \text {. }\end{array}$ & $\begin{array}{l}65.32 \mathrm{e} \\
(82.57) \\
\end{array}$ & $18.12 \mathrm{e}$ & $7.22 \mathrm{e}$ & $1660 \mathrm{f}$ & $\begin{array}{l}35.52 \mathrm{a} \\
(33.75) \\
\end{array}$ & 12.41 & $1220 \mathrm{de}$ & 8.44 \\
\hline$T_{10}$ & Untreated check & $\begin{array}{l}59.52 \mathrm{f} \\
(74.27)\end{array}$ & $15.21 \mathrm{f}$ & $6.42 \mathrm{f}$ & $1286 \mathrm{~g}$ & $\begin{array}{l}38.37 \mathrm{a} \\
(38.53)\end{array}$ & -- & $1117 \mathrm{e}$ & -- \\
\hline & S.Em. \pm & -- & -- & -- & -- & -- & -- & -- & -- \\
\hline & Year & $\mathbf{0 . 8 4}$ & 0.29 & 0.12 & 31.46 & 0.44 & -- & 21.05 & -- \\
\hline & Treatment & 1.75 & 0.60 & 0.26 & 66.95 & 1.02 & -- & 42.84 & -- \\
\hline & $\mathrm{YxT}$ & 2.67 & 0.91 & 0.38 & 99.49 & 1.38 & -- & 66.56 & -- \\
\hline & CD at $5 \%$ & -- & -- & -- & -- & -- & -- & -- & -- \\
\hline & Treatment & 4.99 & 1.71 & 0.73 & 191.35 & 2.90 & -- & 122.10 & -- \\
\hline & YxT & NS & NS & NS & NS & NS & -- & NS & -- \\
\hline & CV\% & 6.54 & 7.20 & 8.42 & 8.10 & 9.30 & -- & 8.64 & -- \\
\hline
\end{tabular}

Note: Treatment means with the letter/ letters in common are not significant by Duncan's New Multiple Range Test at $5 \%$ level of significance.

Figures in parentheses are original values, while those outside are arcsine transformed values. 
Table.2 Economics of various bioagents used for the management of wilt and root rot of chickpea

\begin{tabular}{|c|c|c|c|c|c|c|}
\hline $\begin{array}{l}\text { Sr. } \\
\text { No. }\end{array}$ & Treatments & $\begin{array}{c}\text { Total expenditure } \\
\text { with labour } \\
\text { charges } \\
\text { (Rs./ha) }\end{array}$ & $\begin{array}{c}\text { Grain } \\
\text { yield } \\
\text { (kg/ha) }\end{array}$ & $\begin{array}{l}\text { Income } \\
\text { (Rs./ha) }\end{array}$ & $\begin{array}{c}\text { Additional } \\
\text { income over } \\
\text { control } \\
\text { (Rs./ha) } \\
\end{array}$ & ICBR \\
\hline $\mathrm{T}_{1}$ & $\begin{array}{l}\text { Seed biopriming for } 10 \mathrm{hrs} \text { with suspension of talc based formulation }\left(2 \times 10^{8}\right. \\
\mathrm{cfu} / \mathrm{g}) \text { of Trichoderma viride @ } 50 \mathrm{~g} \text { in } 250 \mathrm{ml} \text { of water } / \mathrm{kg} \text { of seed }\end{array}$ & 375 & 1392 & 97440 & 19250 & $1: 51.33$ \\
\hline $\mathrm{T}_{2}$ & $\begin{array}{l}\text { Seed biopriming for } 10 \mathrm{hrs} \text { with suspension of talc based formulation }\left(2 \times 10^{8}\right. \\
\mathrm{cfu} / \mathrm{g}) \text { of Trichoderma harzianum @ } 50 \mathrm{~g} \text { in } 250 \mathrm{ml} \text { of water } / \mathrm{kg} \text { of seed }\end{array}$ & 375 & 1330 & 93100 & 14910 & $1: 39.76$ \\
\hline $\mathrm{T}_{3}$ & $\begin{array}{l}\text { Seed biopriming for } 10 \text { hrs with suspension of talc based formulation }\left(2 \times 10^{8}\right. \\
\mathrm{cfu} / \mathrm{g}) \text { of Trichoderma virens @ } 50 \mathrm{~g} \text { in } 250 \mathrm{ml} \text { of water } / \mathrm{kg} \text { of seed }\end{array}$ & 375 & 1313 & 91910 & 13720 & $1: 36.59$ \\
\hline $\mathrm{T}_{4}$ & $\begin{array}{l}\text { Seed biopriming for } 10 \mathrm{hrs} \text { with suspension of talc based formulation }\left(2 \times 10^{8}\right. \\
\mathrm{cfu} / \mathrm{g}) \text { of Pseudomonas fluorescens @ } 50 \mathrm{~g} \text { in } 250 \mathrm{ml} \text { of water } / \mathrm{kg} \text { of seed }\end{array}$ & 375 & 1230 & 86100 & 7910 & $1: 21.09$ \\
\hline $\mathrm{T}_{5}$ & $\begin{array}{l}\mathrm{T}_{1}+\text { Soil application of } T \text {. viride enriched FYM (10g/ kg FYM) @ } 100 \mathrm{~g} / \mathrm{m}^{2} \text { of } \\
\text { soil }\end{array}$ & 2900 & 1535 & 107450 & 29260 & 1: 10.09 \\
\hline $\mathrm{T}_{6}$ & $\begin{array}{l}\mathrm{T}_{2}+\text { Soil application of } T . \text { harzianum enriched FYM (10g/ kg FYM) @ } 100 \text { g/ } \\
\mathrm{m}^{2} \text { soil }\end{array}$ & 2900 & 1466 & 102620 & 24430 & $1: 8.42$ \\
\hline $\mathrm{T}_{7}$ & $\begin{array}{l}\mathrm{T}_{3}+\text { Soil application of } T . \text { virens enriched FYM (10g/ kg FYM) @ } 100 \mathrm{~g} / \mathrm{m}^{2} \\
\text { soil }\end{array}$ & 2900 & 1457 & 101990 & 23800 & 1: 8.21 \\
\hline $\mathrm{T}_{8}$ & $\begin{array}{l}\mathrm{T}_{4}+\text { Soil application of } P . \text { fluorescens enriched FYM (10g/ kg FYM) @ } 100 \mathrm{~g} / \\
\mathrm{m}^{2} \text { soil }\end{array}$ & 2900 & 1285 & 89950 & 11760 & 1: 4.06 \\
\hline $\mathrm{T}_{9}$ & $\begin{array}{l}\text { Hydropriming of seed i.e. soaking of chickpea seed @ } 250 \mathrm{ml} \text { of water } / \mathrm{kg} \text { seed } \\
\text { for } 10 \mathrm{hrs} \text {. }\end{array}$ & 75 & 1220 & 85400 & 7210 & $1: 96.13$ \\
\hline $\mathrm{T}_{10}$ & Untreated check & -- & 1117 & 78190 & -- & -- \\
\hline
\end{tabular}

Cost of inputs

\begin{tabular}{|c|l|c|c|l|c|}
\hline S. No. & \multicolumn{1}{|c|}{ Inputs } & Price (Rs.) & Sr. No. & \multicolumn{1}{c|}{ Inputs } & Price (Rs.) \\
\hline 1 & Trichoderma viride & $120 / \mathrm{kg}$ & 5 & Farm Yard Manure (FYM) & $1.25 / \mathrm{kg}$ \\
\hline 2 & Trichoderma harzianum & $120 / \mathrm{kg}$ & 6 & Selling Price of Chickpea & $70 / \mathrm{kg}$ \\
\hline 3 & Trichoderma virens & $120 / \mathrm{kg}$ & 7 & Labour charge per day & $150 / \mathrm{day}$ \\
\hline 4 & Pseudomonas fluorescens & $120 / \mathrm{kg}$ & & & \\
\hline
\end{tabular}


The Trichoderma spp. (T. harzianum, T. hamatum, and $T$. viride) are well documented for being efficacious mycoparasites of soilborne fungi such as Fusarium, Pythium, and Rhizoctonia (Papavizas et al., 1984; Mohiddin et al., 2010). Soil application of T. harzianum, $T$. viride, and $T$. virens has been found to be effective in controlling root rot (Khan and Gupta, 1998; Ganesan et al., 2007; Kumar et al., 2008) and wilt diseases (Prasad et al., 2002; Dubey et al., 2012). These species multiply rapidly in soil infested with Fusarium and Rhizoctonia (Khan et al., 2011), evidenced by the significantly greater populations of Trichoderma spp. in the pathogen-infested soils. Increase in the CFU count of Trichoderma spp. can be attributed to the availability of host pathogens ( $F$. oxysporum and $R$. solani) on which these mycoparasites grow and multiply rapidly (Jefries and Young, 1994). The present study has demonstrated that Trichoderma viride or T. harzianum can be used for controlling wilt and root rot disease complexes of chickpeas in organic farming or in low-input sustainable agriculture. The yield enhancement was also good with the BCAs. In the present study, seed biopriming and soil application of $T$. viride or $T$. harzianum provided better disease control with greater crop yield enhancement. The present research may encourage farmers to integrate bioagents into chickpea agronomy.

\section{Acknowledgement}

The authors are grateful to Dr. K. P. Patel, Principal \& Dean, Faculty of Agriculture, AAU, Anand as well as higher authorities of the university for providing necessary facilities for research work and is dully acknowledge.

\section{References}

Abd-El-Khair, H., Khalifa, R.K.M. and Haggag, K.H.E. 2010. Effect of Trichoderma species on damping-off diseases incidence, some plant enzymes activity and nutritional status of bean plants. J. American Sci., 6: 486497.
Abdul Baki, A. and Anderson, J.D. 1973. Vigour determination in soybean seed by multiple criteria. Crop Sci., 13: 630-633.

Andrabi, M., Vaid, A. and Razdan, V.K. 2011. Evaluation of different measures to control wilt causing pathogens in chickpea. J. Plant Protection Res., 5: 51-59.

Bhatti, M.A., Ali, S. and Khan, I.U. 1987. Pathogenicity of fungi associated with wilt of chickpea with special reference to Verticillium albo-atrum. Pak. J. Agri. Res. 8: 39-42.

Bruckner, H. and Przybylski, M. 1984. Isolation and structural characterization of polypeptides antibiotics of the peptaibol class by high-performance liquid chromatography with field and fast atom bombardment mass spectrometry. $J$. Chromatography, 296: 263-275.

Chattopadhyay, S.B. and Sen Gupta, P.K. 1967. Studies on wilt diseases of pulses I. Variation and taxonomy of Fusarium spp. associated with the wilt disease of pulses. Indian J. Mycol. Res., 5: 45-53.

Dubey, S.C., Tripathi, A. and Singh, B. 2012. Combination of soil application and seed treatment formulations of Trichoderma species for integrated management of wet root rot caused by Rhizoctonia solani in chickpea (Cicer arietinum). Indian J. Agri. Sci., 82: 356-362.

Ganesan, S., Kuppusamy, R.G. and Sekar, R. 2007. Integrated management of stem rot disease (Sclerotium rolfsii) of groundnut (Arachis hypogaea L.) using rhizobium and Trichoderma harzianum (ITCC - 4572). Turkish J. Agri. Forestry, 31: 103-108.

Haware, M.P. and Nene, Y.L. 1980. Influence of wilt at different stages on the yield loss in chickpea. Trop. Grain Legume Bull., 19: 38-40.

Haware, M. P., Nene, Y. L. and Rajeswari, R. 1978. Eradication of Fusarium oxysporum f. sp. ciceri transmitted in chickpea seed. Phytopathol., 68: 1364-1368.

Haware, M. P., Nene, Y. L. and Natarajan, M. 1996. The survival of Fusarium oxysporum f. sp. ciceri in soil in the absence of chickpea. Phytopathologia Mediterranea, 35: 12-19. 
Jalali, B.L. and Chand, H. 1992. Chickpea wilt. In: Singh, U.S., Mukhopadhyay, A. N., Kumar, J. and Chaube, H. S., editors. Diseases of International Importance, Vol 1. Upper Saddle River, NJ, USA: Prentice Hall, pp. 429-464.

Jefries, P. and Young, T.W.K. 1994. Interfungal Parasitic Relationship. Wallingford, UK: CAB International.

Kaur, N. P. and Mukhopadhyay, A.N. 1992. Integrated control of chickpea wilt complex by Trichoderma and chemical methods in India. Trop. Pest Management, 38, 372375.

Khan, M. R., Ashraf, S., Rasool, F., Salati, K. M., Mohiddin, F. A. and Haque, Z. 2014. Field performance of Trichoderma species against wilt disease complex of chickpea caused by Fusarium oxysporum f. sp. ciceri and Rhizoctonia solani. Turkish J. Agric. Forestry, 38: 447-454.

Khan, M. R. and Gupta, J. 1998. Antagonistic efficacy Trichoderma species against Macrophomina phaseolina on eggplant. $J$. Plant Dis. Protection, 105: 387-393.

Khan, M.R., Anwer, M.A. and Shahid, S. 2011. Management of gray mould of chickpea, Botrytis cinerea with bacterial and fungal biopesticides using different modes of inoculation and application. Biol. Control, 57: 13-23.

Khan, M.R., Khan, S.M. and Mohiddin, F.A. 2004. Biological control of Fusarium wilt of chickpea through seed treatment with the commercial formulation of Trichoderma harzianum and Pseudomonas fluorescens. Phytopathologia Mediterranea, 43: 20-25.

Kumar, M., Jain, A.K., Kumar, P., Chaudhary, S. and Kumar, S. 2008. Bioefficacy of Trichoderma spp. against management of chickpea damping-off caused by Rhizoctonia solani Kuhn. Plant Archi., 8: 399-400.

\section{How to cite this article:}

Pandey R.N., N.M. Gohel and Pratik Jaisani. 2017. Management of Wilt and Root Rot of Chickpea caused by Fusarium oxysporum f. sp. ciceri and Macrophomina phaseolina through Seed Biopriming and Soil Application of Bio-Agents. Int.J.Curr.Microbiol.App.Sci. 6(5): 2516-2522.

doi: https://doi.org/10.20546/ijcmas.2017.605.282
Lorito, P., Emerson, O.H. and Lomas, N. 1993. The isolation of toxic substances from the culture filtrate of Trichoderma. Phytopathol., 26: 1068-1068.

Malathi, P. and Sabitha, D. 2004. Effect of seed priming with Trichoderma on seed borne infection of Macrophomina phaseolina and seed quality in groundnut. Annals of Plant Protection Sci., 12(1): 87-91.

Manjunatha, S.V., Naik, M. K., Khan, M. F. R. and Goswami, R.S. 2013. Evaluation for bio-control agents for management of dry root rot of chickpea caused by Macrophomina phaseolina. Crop Protection, 45: 147-150.

Mohiddin, F.A., Khan, M. R. and Khan, S. M. 2010. Why Trichoderma is considered superhero (super fungus) against the evil parasites? Plant Pathol. J., 9: 92-102.

Papavizas, G. C., Dunn, M. T., Lewis, J. A. and Beagle-Ristaino, J. $1984 . \quad$ Liquid fermentation technology for experimental production of biocontrol fungi. Phytopathol., 74: 1171-1175.

Prasad, R. D., Rangeshwaran, R., Anuroop, C. P. and Rashmi, H.J. 2002. Biological control of wilt and root rot of chickpea under field conditions. Annals of Plant Protection Sci., 10: $72-75$.

Rudresh, D.L., Shivaprakash, M.K. and Prasad, R.D. 2005. Potential of Trichoderma spp. as biocontrol agents of pathogens involved in wilt complex of chickpea (Cicer arietinum L.). J. Biol. Control, 19: 157166.

Singh, R.S. 2005. Plant diseases, Eighth Edition, Oxford \& IBH Publishing Co. Pvt Ltd., New Delhi.

Tomar, O.K., Singh, D. and Singh, D. 2010. Stability for yield and related traits in chickpea (Cicer arietinum). Indian J. Agri. Sci., 80: 1076-1080. 